\title{
Article \\ Prion Strains Differ in Susceptibility to Photodynamic Oxidation
}

\author{
Marie Kostelanska and Karel Holada *D \\ Institute of Immunology and Microbiology, First Faculty of Medicine, Charles University, \\ 12800 Prague, Czech Republic; marie.kostelanska@lf1.cuni.cz \\ * Correspondence: karel.holada@lf1.cuni.cz; Tel.: +420-22496-8503
}

check for

updates

Citation: Kostelanska, M.; Holada, K. Prion Strains Differ in Susceptibility to Photodynamic Oxidation. Molecules 2022, 27, 611. https:// doi.org/10.3390/molecules27030611

Academic Editor: Maksymilian Chruszcz

Received: 2 December 2021

Accepted: 14 January 2022

Published: 18 January 2022

Publisher's Note: MDPI stays neutral with regard to jurisdictional claims in published maps and institutional affiliations.

Copyright: (c) 2022 by the authors. Licensee MDPI, Basel, Switzerland. This article is an open access article distributed under the terms and conditions of the Creative Commons Attribution (CC BY) license (https:/ / creativecommons.org/licenses/by/ $4.0 /)$.

\begin{abstract}
Prion disorders, or transmissible spongiform encephalophaties (TSE), are fatal neurodegenerative diseases affecting mammals. Prion-infectious particles comprise of misfolded pathological prion proteins ( $\mathrm{PrP}^{\mathrm{TSE}}$ ). Different TSEs are associated with distinct $\mathrm{PrP}^{\mathrm{TSE}}$ folds called prion strains. The high resistance of prions to conventional sterilization increases the risk of prion transmission in medical, veterinary and food industry practices. Recently, we have demonstrated the ability of disulfonated hydroxyaluminum phthalocyanine to photodynamically inactivate mouse RML prions by generated singlet oxygen. Herein, we studied the efficiency of three phthalocyanine derivatives in photodynamic treatment of seven mouse adapted prion strains originating from sheep, human, and cow species. We report the different susceptibilities of the strains to photodynamic oxidative elimination of PrPTSE epitopes: RML, A139, Fu-1 > mBSE, mvCJD > ME7, 22L. The efficiency of the phthalocyanine derivatives in the epitope elimination also differed $\left(\mathrm{AlPcOH}\left(\mathrm{SO}_{3}\right)_{2}>\mathrm{ZnPc}\left(\mathrm{SO}_{3}\right)_{1-3}\right.$ $\left.>\operatorname{SiPc}(\mathrm{OH})_{2}\left(\mathrm{SO}_{3}\right)_{1-3}\right)$ and was not correlated to the yields of generated singlet oxygen. Our data suggest that the structural properties of both the phthalocyanine and the $\mathrm{PrP}^{\mathrm{TSE}}$ strain may affect the effectiveness of the photodynamic prion inactivation. Our finding provides a new option for the discrimination of prion strains and highlights the necessity of utilizing range of prion strains when validating the photodynamic prion decontamination procedures.
\end{abstract}

Keywords: prion; PrP; TSE; strain; protein folding; phthalocyanine; photodynamic; PDI; singlet oxygen; prion inactivation

\section{Introduction}

Prion disorders, also known as transmissible spongiform encephalopathies (TSE), represent a group of fatal neurodegenerative diseases affecting man and several other mammalian species. Within the same species, TSE can differ in the length of preclinical phase, clinical signs, speed of progression, location of brain lesions and also in biochemical properties of accumulated pathological $\mathrm{PrP}^{\mathrm{TSE}}$ [1]. Most of the patterns seem to be explained by the existence of so-called prion strains represented by distinct self-propagating $\operatorname{PrP}^{\mathrm{TSE}}$ conformations [2]. Prions are exceptionally resistant to conventional heat and chemical-based sterilization procedures [3]. The World Health Organization recommends the immersion of contaminated instruments in $1 \mathrm{M} \mathrm{NaOH}$ or $2 \% \mathrm{NaOCl}$ for $1 \mathrm{~h}$, followed by autoclaving at $134{ }^{\circ} \mathrm{C}$ for $1 \mathrm{~h}$ and subsequent routine sterilization. However, such harsh treatment is not appropriate for various medical instruments, and several less-damaging procedures have been studied, some with encouraging results [4,5]. Interestingly, prion strains notably differ in their resistance to inactivation. For example, the hamster Sc237 strain was shown to be five orders of magnitude more sensitive to acidic SDS treatment than human CJD prions [6]. Notable variation was also found in the thermostability of mouse-adapted prion strains [7]. Out of the two most commonly used laboratory mouse scrapie strains, lymphotropic RML and neurotropic ME7, the ME7 strain displays notably higher stability of PrPTSE core to denaturation [8]. We have previously demonstrated inactivation of mouse RML prions by photodynamic treatment with disulfonated hydroxyaluminum phthalocyanine $\left(\mathrm{AlPcOH}\left(\mathrm{SO}_{3}\right)_{2}\right)[9,10]$. Whether the susceptibility of prions to photodynamic treatment 
varies among the prion strains is at present unknown. In this study, we utilized seven mouse-adapted prion strains (Fu-1, mvCJD, mBSE, ME7, 22L, 139A and RML). Two strains were of human origin, Fukuoka-1 (Fu-1) and mvCJD were derived from the tissues of Gerstmann-Sträussler-Scheinker syndrome and variant Creutzfeldt-Jakob disease patients, respectively [11]. Mouse-adapted BSE (mBSE) was derived from the tissue of cattle affected by bovine spongiform encephalopathy. The ME7, 139A, RML and 22L strains originated from sheep scrapie. The strains RML, 139A and 22L were isolates from the same sheep, but they followed varying passaging through goats (RML, 139A) or sheep (22L) before adapting to mice. The ME7 strain was derived from sheep independently [12]. The RML and 139A strains are believed to originate from the same mouse isolate, but were adapted to mice in separate laboratories and behave differently [13].

Within the prion field, the phthalocyanine $\left(\mathrm{Pc}_{\mathrm{c}}\right)$ derivatives were first studied as potent anti-prion compounds able to cure cell cultures from prion infection and even prolong the survival of prion infected mice $[14,15]$. The anti-prion activity of Pc derivatives correlated with their self-association tendencies [16]. The mechanistic explanation of their effect predicted $\pi-\pi$ interactions of planar Pc molecule with aromatic amino acid residues of $\operatorname{PrP}[16,17]$. The direct binding of up to $10 \mathrm{Pc}$ molecules to 1 molecule of recombinant hamster PrP with micromolar affinity was demonstrated by Dee et al. [18]. Pcs have been used in various photo-applications, including phototherapy of cancer, bioimaging and the photodynamic inactivation (PDI) of microorganisms $[19,20]$. Our laboratory was the first to utilize Pc for the PDI of prions [9]. The treatment of RML brain homogenate with $\mathrm{AlPcOH}\left(\mathrm{SO}_{3}\right)_{2}$ led to the disappearance of the $\mathrm{PrP}^{\mathrm{TSE}}$ signal detected by Western blot, decreased its infectivity in cell culture assay and, importantly, also significantly decreased its infectivity in mouse bioassay $[9,10]$. The mechanism behind the photodynamic elimination of $\mathrm{PrP}^{\mathrm{TSE}}$ epitopes and prion inactivation relies on phthalocyanine's generation of singlet oxygen $\mathrm{O}_{2}\left({ }^{1} \Delta_{\mathrm{g}}\right)$ [10]. The reaction of $\mathrm{O}_{2}\left({ }^{1} \Delta_{\mathrm{g}}\right)$ with proteins is known to preferentially modify the side residues of five amino acids: $\mathrm{W}, \mathrm{Y}, \mathrm{H}, \mathrm{M}$ and $\mathrm{C}$ [21].

The goal of this study was to evaluate the potential of three sulfonated Pc derivatives $\mathrm{ZnPc}\left(\mathrm{SO}_{3}\right)_{1-3}, \mathrm{AlPcOH}\left(\mathrm{SO}_{3}\right)_{2}$ and $\mathrm{SiPc}(\mathrm{OH})_{2}\left(\mathrm{SO}_{3}\right)_{1-3}$ for the PDI of prions and to examine if the susceptibility of prions toward photodynamic treatment is prion strain dependent. We found significant differences both in the efficiency of Pc derivatives and in the susceptibility of the strains.

\section{Results}

\subsection{Phthalocyanine Derivatives Characterization}

\subsubsection{Differences in the Phthalocyanine Structure}

The Pc derivatives differed in the nature of the central metal atom ( $\mathrm{Al}, \mathrm{Zn}, \mathrm{Si})$, the level of the metal hydroxylation (from zero to two) and the number of substituting sulfonate groups on their peripheral benzene rings (Figure 1, Table 1).

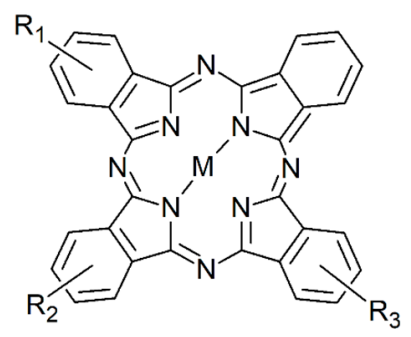

Figure 1. Structure of sulfonated metal phthalocyanines, where $\mathrm{M}$ represents coordinated central metal, and $\mathrm{R}_{1}=\mathrm{R}_{2}=\mathrm{R}_{3}$ indicates the position of $\mathrm{SO}_{3}$ substituents of peripheral benzene rings. 
Table 1. Phthalocyanine derivatives utilized in the study.

\begin{tabular}{ccc}
\hline Phthalocyanine Derivative & Coordinated Metal & Peripheral Sulfonation \\
\hline $\mathrm{SiPc}(\mathrm{OH})_{2}\left(\mathrm{SO}_{3}\right)_{1-3}$ & $\mathrm{HO}-\mathrm{Si}-\mathrm{OH}$ & $\mathrm{R} 1 \Lambda \mathrm{R} 2 \Lambda \mathrm{R} 3^{1}$ \\
$\mathrm{ZnPc}\left(\mathrm{SO}_{3}\right)_{1-3}$ & $\mathrm{Zn}$ & $\mathrm{R} 1 \Lambda \mathrm{R} 2 \Lambda \mathrm{R} 3^{1}$ \\
$\mathrm{AlPcOH}\left(\mathrm{SO}_{3}\right)_{2}$ & $\mathrm{Al}-\mathrm{OH}$ & $\mathrm{R} 1 \Lambda \mathrm{R} 2$ or $\mathrm{R} 1 \Lambda \mathrm{R} 3^{2}$ \\
\hline
\end{tabular}

${ }^{1}$ The mixture of mono-, di- and tri- sulfonated phthalocyanine stereoisomers; ${ }^{2}$ The mixture of di-sulfonanted phthalocyanine stereoisomers.

\subsubsection{Spectroscopic Properties and Production of Singlet Oxygen}

The absorption spectra of Pcs contained maxima at $663 \mathrm{~nm}$ for $\mathrm{ZnPc}\left(\mathrm{SO}_{3}\right)_{1-3}$, at $675 \mathrm{~nm}$ for $\mathrm{AlPcOH}\left(\mathrm{SO}_{3}\right)_{2}$ and at $679 \mathrm{~nm}$ for $\mathrm{SiPc}(\mathrm{OH})_{2}\left(\mathrm{SO}_{3}\right)_{1-3}$. The spectrum of $\mathrm{ZnPc}\left(\mathrm{SO}_{3}\right)_{1-3}$ contained a second maxima at $630 \mathrm{~nm}$, suggesting the presence of Pc dimers [22], which were not detected in the spectra of the other derivatives (Figure 2a). The absorption peaks overlapped with the emission peak of the LEDs utilized for the photodynamic treatment. The dissolution of Pcs in DMSO led to the increase in their absorbance $1.8 \times$ for $\mathrm{SiPc}(\mathrm{OH})_{2}\left(\mathrm{SO}_{3}\right)_{1-3}, 1.9 \times$ for $\mathrm{AlPcOH}\left(\mathrm{SO}_{3}\right)_{2}$ and $3.8 \times$ for $\mathrm{ZnPc}\left(\mathrm{SO}_{3}\right)_{1-3}$, reflecting the different aggregation statuses of the derivatives in PBS (Figure $2 b$ ).

(a)

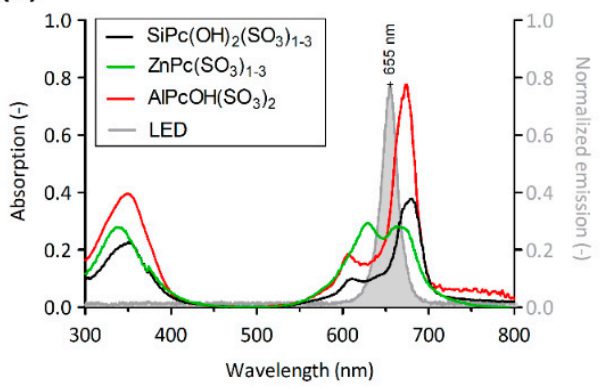

(b)

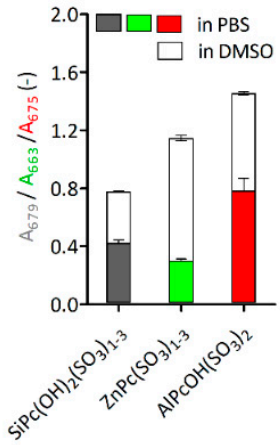

(c)

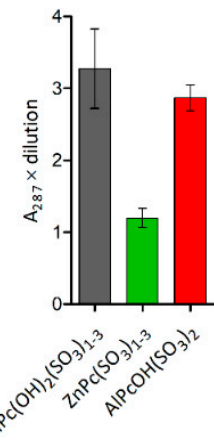

Figure 2. Phthalocyanine absorption spectra, aggregation state and $\mathrm{O}_{2}\left({ }^{1} \Delta_{\mathrm{g}}\right)$ production. (a) Absorption spectra of Pc derivatives in PBS (10 $\mu \mathrm{g} \mathrm{mL}^{-1}$; red, green and black lines) and emission spectrum of LED light (gray peak) normalized to the maximal Pc absorption. (b) Absorption maxima of Pc derivatives in PBS and in DMSO $(n=3)$. (c) Relative production of $\mathrm{O}_{2}\left({ }^{1} \Delta_{\mathrm{g}}\right)$ during photoactivation of Pc derivatives in iodide solution $(n=3)$.

The photoactivation of Pcs leads to the generation of highly reactive $\mathrm{O}_{2}\left({ }^{1} \Delta_{\mathrm{g}}\right)$, which is responsible for the PDI of prions [10]. The potency of the studied derivatives to produce $\mathrm{O}_{2}\left({ }^{1} \Delta_{\mathrm{g}}\right)$ was compared under the same experimental conditions. The amount of $\mathrm{O}_{2}\left({ }^{1} \Delta_{\mathrm{g}}\right)$ was estimated by the spectrophotometric method [23]. $\mathrm{SiPc}(\mathrm{OH})_{2}\left(\mathrm{SO}_{3}\right)_{1-3}$ and $\mathrm{AlPcOH}\left(\mathrm{SO}_{3}\right)_{2}$ produced similar relative $\left(\mathrm{A}_{287} \times\right.$ dilution) amounts of $\mathrm{O}_{2}\left({ }^{1} \Delta_{\mathrm{g}}\right), 3.3 \pm 0.5$ and $2.9 \pm 0.2$, respectively. The amount of $\mathrm{O}_{2}\left({ }^{1} \Delta_{\mathrm{g}}\right)$ released by $\mathrm{ZnPc}\left(\mathrm{SO}_{3}\right)_{1-3}(1.2 \pm 0.1)$ was approximately $2.7 \times$ and $2.4 \times$ lower, respectively (Figure $2 \mathrm{c}$ ). Neither the illuminated iodide solution alone nor the Pcs in iodide solution left in the dark produced false positive reactions.

\subsection{Photodynamic Elimination of Prion Epitopes}

2.2.1. Demonstration of Epitopes Elimination by a Panel of Prion Antibodies

The locations of the epitopes of nine prion monoclonal antibodies utilized in the study are depicted in Figure 3. Each epitope contains at least one $\mathrm{O}_{2}\left({ }^{1} \Delta_{\mathrm{g}}\right)$ sensitive amino acid residue. The photodynamic treatment of $1 \%(w / v)$ RML brain homogenate with $\mathrm{ZnPc}\left(\mathrm{SO}_{3}\right)_{1-3}$ or $\mathrm{AlPcOH}\left(\mathrm{SO}_{3}\right)_{2}$ followed a similar pattern for all tested antibodies. The Pcs at the concentration $0.1 \mu \mathrm{g} \mathrm{mL}^{-1}$ diminished and at the concentration $1 \mu \mathrm{g} \mathrm{mL}^{-1}$ fully eliminated the signal of proteinase $\mathrm{K}$ resistant $\operatorname{PrP}^{\mathrm{TSE}}$ of all tested antibodies (Figure 4). At the same time, the binding of DC2 and AG4 to proteinase-K-sensitive diglycosylated isoform 
of $\mathrm{PrPC}^{\mathrm{C}}$ was not fully abolished, and the protein displayed slightly lower electrophoretic mobility (Figure 4). No change in the signal was recorded in the control aliquots containing the Pcs but kept in the dark.

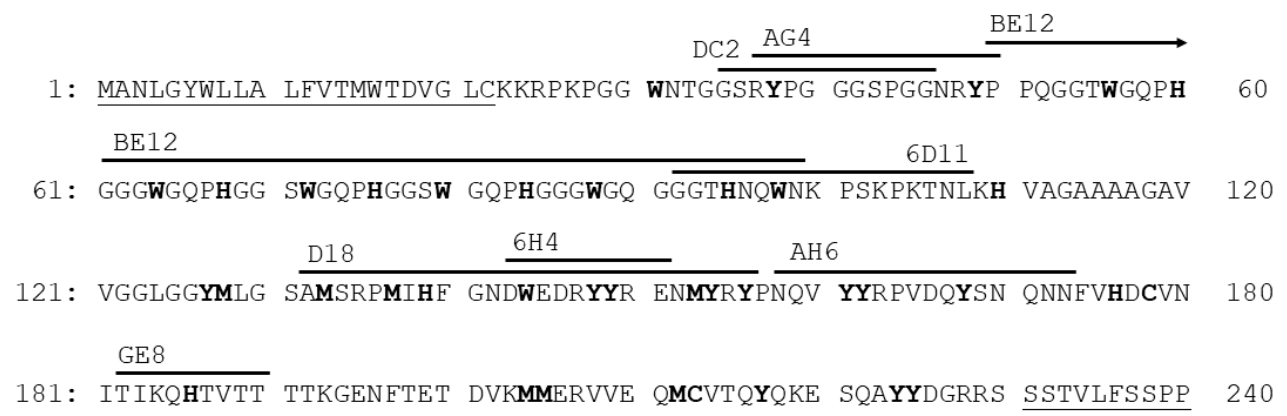

Figure 3. Amino acid sequence of mouse prion protein (UniProt P04925) with the location of epitopes of monoclonal antibodies DC2 (aa35-46), AG4 (aa37-50), BE12 (aa50-99), 6D11 (aa93-109), D18 (aa132-156), 6H4 (aa144-152), AH6 (aa159-174) and GE8 (aa183-191). Underlined letters mark signal sequences which are cleaved off. The amino acid residues prone to oxidation by $\mathrm{O}_{2}\left({ }^{1} \Delta_{\mathrm{g}}\right)$ are depicted in bold.

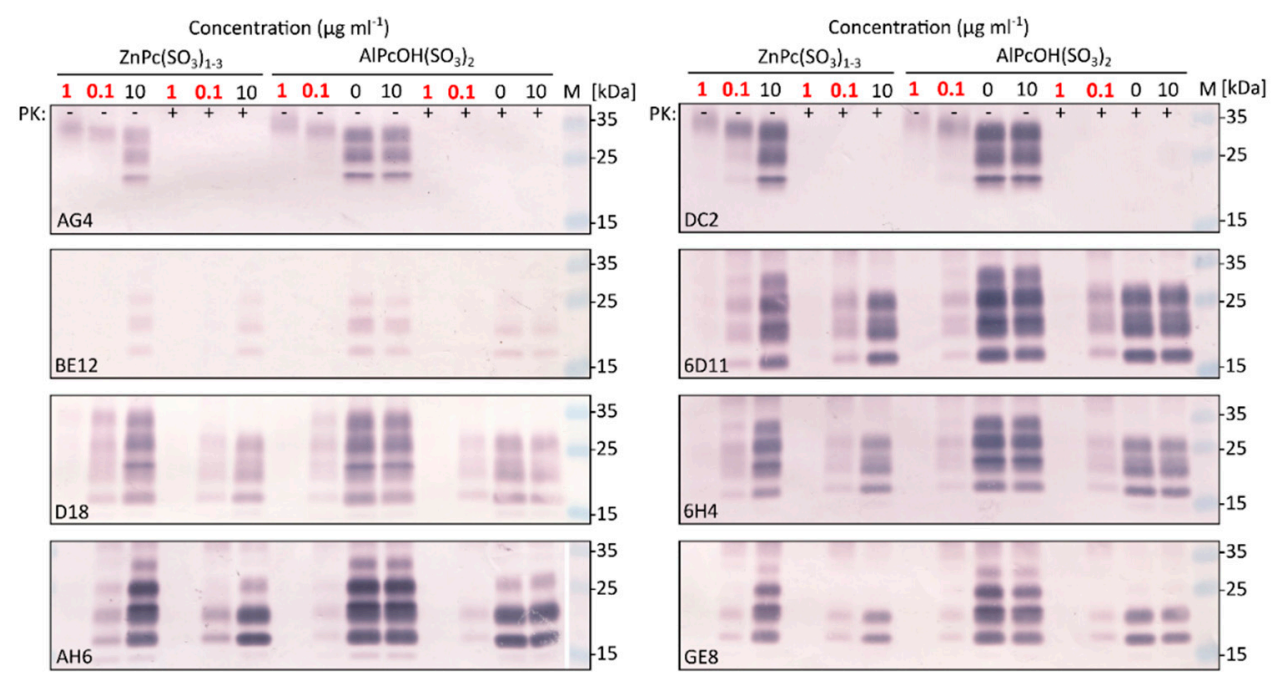

Figure 4. Photodynamic elimination of $\mathrm{PrP}^{\mathrm{C}}$ and / or $\operatorname{Pr} \mathrm{P}^{\mathrm{TSE}}$ epitopes proved by failure of antibodies binding. RML brain homogenate with 0.1 or $1 \mu \mathrm{g} \mathrm{mL}{ }^{-1} \mathrm{ZnPc}\left(\mathrm{SO}_{3}\right)_{1-3}$ or $\mathrm{AlPcOH}\left(\mathrm{SO}_{3}\right)_{2}$ was illuminated for $90 \mathrm{~min}$ (red numbers) and control aliquots kept in dark either non-treated or with $10 \mu \mathrm{g} \mathrm{mL}^{-1}$ of the Pc derivative (black numbers). One aliquot of each sample was cleaved with proteinase $\mathrm{K}(\mathrm{PK} ;+)$ to remove protease sensitive $\mathrm{PrP}^{\mathrm{C}}$ and visualize $\mathrm{PrP}^{\mathrm{TSE}}$. $\mathrm{PK}$ treatment cleaves off the N-terminal part of $\mathrm{PrP}^{\mathrm{TSE}}$, resulting in its higher electrophoretic mobility and removal of DC2 and AG4 epitopes. The second aliquot was left intact (-) and contained both $\operatorname{PrP}^{\mathrm{C}}$ and $\operatorname{PrP}^{\mathrm{TSE}}$. The samples were analyzed by Western blot with antibodies against different parts of PrP molecule (DC2, AG4, BE12, 6D11, D18, 6H4, AH6, GE8). The photodynamic elimination of the epitopes was documented for all tested antibodies. The figure is a representative of three independent experiments.

2.2.2. Differences in the Potency of Phthalocyanine Derivatives and in the Sensitivity of Prion Strains

The potency of Pcs derivatives in the photodynamic $\operatorname{PrP}^{\mathrm{TSE}}$ epitope elimination was compared at concentration $1 \mu \mathrm{g} \mathrm{mL}{ }^{-1} \cdot \operatorname{AlPcOH}\left(\mathrm{SO}_{3}\right)_{2}$ was able to decrease the PrPres signal below the detection limit of the Western blot for the mBSE, mvCJD, Fu-1, 139A and RML strains. The less efficient $\mathrm{ZnPc}\left(\mathrm{SO}_{3}\right)_{1-3}$ removed the signal for the $\mathrm{Fu}-1,139 \mathrm{~A}$ 
and RML strains. In contrast, $\mathrm{SiPc}(\mathrm{OH})_{2}\left(\mathrm{SO}_{3}\right)_{1-3}$ did not eliminated the PrPres signal of any of the tested strains (Figure 5). ME7 and 22L were the least susceptible strains to photodynamic treatment and resisted PrPres signal elimination under the tested conditions. The PrPres signals of the mBSE and mvCJD strains were eliminated only by the most efficient $\mathrm{AlPcOH}\left(\mathrm{SO}_{3}\right)_{2}$. The PrPres signals of strains 139A, RML and Fu-1 were removed by both $\mathrm{AlPcOH}\left(\mathrm{SO}_{3}\right)_{2}$ and $\mathrm{ZnPc}\left(\mathrm{SO}_{3}\right)_{1-3}$. The semi-quantitative estimation of the remaining PrPres Western blot signals was performed by densitometry (Figure $5 \mathrm{~b}$ ). The residual signal after the treatment with $\mathrm{AlPcOH}\left(\mathrm{SO}_{3}\right)_{2}$ or $\mathrm{ZnPc}\left(\mathrm{SO}_{3}\right)_{1-3}$ was between 0 and $20 \%$ for all tested prion strains. The signal after the treatment with $\mathrm{SiPc}(\mathrm{OH})_{2}\left(\mathrm{SO}_{3}\right)_{1-3}$ varied between 35 and $100 \%$. These results allow discrimination of the prion strains into three groups according to their sensitivity to the $\operatorname{PrP}^{\mathrm{TSE}}$ epitope elimination (Figure 5c).

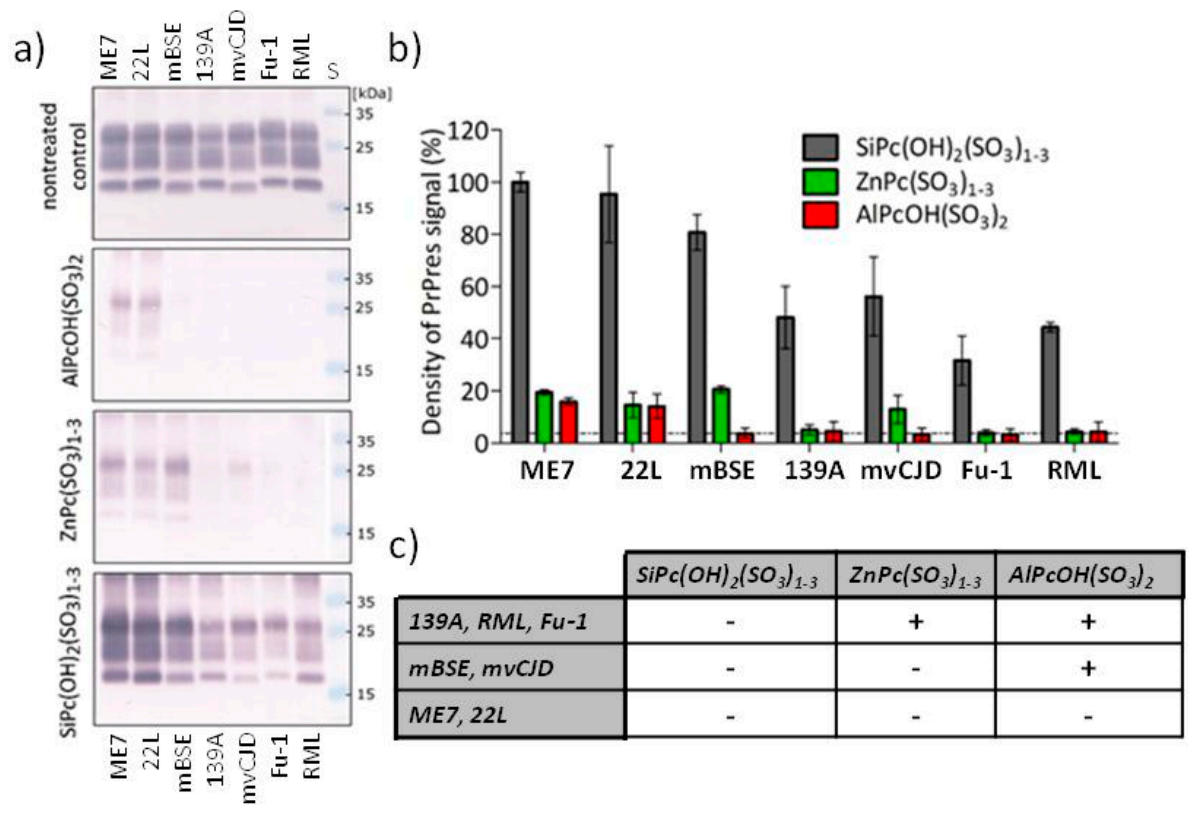

Figure 5. Photodynamic elimination of $\mathrm{PrP}^{\mathrm{TSE}}$ signal by Pc derivatives. (a) Western blot analysis of photodynamic elimination of $\mathrm{PrP}^{\mathrm{TSE}}$ signal induced by photoactivation with $\mathrm{AlPcOH}\left(\mathrm{SO}_{3}\right)_{2}$, $\mathrm{ZnPc}\left(\mathrm{SO}_{3}\right)_{1-3}$ and $\mathrm{SiPc}(\mathrm{OH})_{2}\left(\mathrm{SO}_{3}\right)_{1-3}$. PrP $\mathrm{PSE}^{\mathrm{TSE}}$ in the brain homogenates infected by different prion strains (ME7, 22L, mBSE, 139A, mvCJD, Fu-1, RML) was detected using the antibody 6D11 as proteinase K-resistant fragments PrPres. S; molecular weight standard. The Western blots are representative of three independent experiments. (b) Densitometry evaluation of the PrPres signal on Western blot membranes $(n=3)$. Dotted line represents the background signal. (c) Discrimination of the prion strains based on their sensitivity to photodynamic treatment by Pc derivatives. The strain was considered sensitive (+) when the average signal of PrPres on the Western blot reduced by SD is lower than the background.

\section{Discussion}

Previously, we have demonstrated that the photodynamic treatment of RML prions by $\mathrm{AlPcOH}\left(\mathrm{SO}_{3}\right)_{2}$ leads to a time- and dose-dependent disappearance of PrPTSE signal on Western blots $[9,10]$. The elimination of the $\operatorname{PrP}^{\mathrm{TSE}}$ epitopes was accompanied by a significant decrease in prion infectivity for susceptible CAD5 cells. In the follow up study, we have improved the treatment effectiveness by the utilization of an optimized light source. The concentration of $\mathrm{AlPcOH}\left(\mathrm{SO}_{3}\right)_{2}$ needed to decrease the PrP ${ }^{\mathrm{TSE}}$ Western blot signal by $50 \%$ was as low as $22 \mathrm{nM}$ [10]. The treatment significantly reduced the infectivity of RML prions adsorbed onto plastic, suggesting its possible potential in the sanitization of prion-contaminated surfaces. Importantly, the prion infectivity of photodynamically treated RML brain homogenate was diminished by more than $4 \log _{10}$ in the mouse bioassay [10]. At the same time, the infectivity of the sample with $\mathrm{AlPcOH}\left(\mathrm{SO}_{3}\right)_{2}$ left in dark did not change confirming that the effect was not caused by the presence of Pc itself. Caughey 
et al. demonstrated that the direct anti-prion activity of Pc derivatives (not dependent on photoactivity) correlated with their propensity for self-aggregation in aqueous media [16]. However, the self-aggregation of Pcs is known to inhibit their photoactivity as only monomer Pc molecules are capable to generate $\mathrm{O}_{2}\left({ }^{1} \Delta_{\mathrm{g}}\right)$ [22]. This raises the question if the $\mathrm{AlPcOH}\left(\mathrm{SO}_{3}\right)_{2}$ utilized in our previous studies was efficient in $\mathrm{PrP}^{\mathrm{TSE}}$ oxidation just due to its low self-aggregation and high $\mathrm{O}_{2}\left({ }^{1} \Delta_{\mathrm{g}}\right)$ production.

To learn more about the importance of Pc characteristics for photodynamic inactivation of prions, we utilized three Pcs differing in sulfonation, coordinated central metal, level of aggregation and $\mathrm{O}_{2}\left({ }^{1} \Delta_{\mathrm{g}}\right)$ production. While $\mathrm{AlPcOH}\left(\mathrm{SO}_{3}\right)_{2}$ was exactly di-sulfonated, $\mathrm{ZnPc}\left(\mathrm{SO}_{3}\right)_{1-3}$ and $\mathrm{SiPc}(\mathrm{OH})_{2}\left(\mathrm{SO}_{3}\right)_{1-3}$ were mixes of mono-, di- and tri-sulfonated molecules. The absorption spectra of $\mathrm{AlPcOH}\left(\mathrm{SO}_{3}\right)_{2}$ and $\mathrm{SiPc}(\mathrm{OH})_{2}\left(\mathrm{SO}_{3}\right)_{1-3}$ in PBS suggested that the $\mathrm{Pcs}$ were predominantly in the monomeric state. In contrast, the spectra of $\mathrm{ZnPc}\left(\mathrm{SO}_{3}\right)_{1-3}$ implied a substantial presence of dimers [22]. Likewise, the dissolution of the Pcs in DMSO led to a notably higher increase in the $\mathrm{ZnPc}\left(\mathrm{SO}_{3}\right)_{1-3} \mathrm{Q}$ band absorbance, confirming its higher aggregation in PBS [22]. The higher aggregation of $\mathrm{ZnPc}\left(\mathrm{SO}_{3}\right)_{1-3}$ correlated with its markedly lower photogeneration of $\mathrm{O}_{2}\left({ }^{1} \Delta_{\mathrm{g}}\right)$ in comparison to the other two derivatives. The $\mathrm{O}_{2}\left({ }^{1} \Delta_{\mathrm{g}}\right)$ production by $\mathrm{SiPc}(\mathrm{OH})_{2}\left(\mathrm{SO}_{3}\right)_{1-3}$ was slightly higher than by $\mathrm{AlPcOH}\left(\mathrm{SO}_{3}\right)_{2}$, as reported earlier [10].

All our previous inactivation studies were carried out with the RML strain of mouseadapted scrapie. However, prion strains can substantially differ in their susceptibility to denaturation and inactivation [6-8]. To find out whether this is also the case for the photodynamic oxidation, we studied its effect on seven laboratory strains of prions. All strains were propagated in CD-1 mice and as a source of prions served identically prepared brain homogenates of symptomatic animals.

In our previous studies, we have used antibodies DC2 and AH6 to demonstrate the disappearance of PrP ${ }^{\mathrm{TSE}}$ signal on Western blots $[9,10]$. To verify that the photodynamic treatment also affects other parts of the $\mathrm{PrP}^{\mathrm{TSE}}$ molecule, we utilized a panel of antibodies directed against different parts of the protein. The treatment caused similar changes in the binding of all tested antibodies, suggesting that the photodynamic oxidation affects the entire PrP ${ }^{\mathrm{TSE}}$ molecule. This finding seems to correlate with relatively even spread of $\mathrm{O}_{2}\left({ }^{1} \Delta_{\mathrm{g}}\right)$-sensitive amino acid residues [21] along the protein sequence. The sensitivity of the strains to the photodynamic oxidation was monitored using the antibody 6D11. The 6D11 epitope is located at the beginning of proteinase K-resistant part of PrP ${ }^{\mathrm{TSE}}$, contains two amino acid residues sensitive to $\mathrm{O}_{2}\left({ }^{1} \Delta_{\mathrm{g}}\right)$ and gave robust Western blot signal.

The treatment of the strains with Pc derivatives led to a reproducible pattern. $\mathrm{ZnPc}\left(\mathrm{SO}_{3}\right)_{1-3}$ and $\mathrm{AlPcOH}\left(\mathrm{SO}_{3}\right)_{2}$ eliminated the PrP ${ }^{\mathrm{TSE}}$ signal in three and five tested prion strains, respectively. In contrast, identical treatment with $\mathrm{SiPc}(\mathrm{OH})_{2}\left(\mathrm{SO}_{3}\right)_{1-3}$ did not eliminate the signal in any out of seven strains tested, despite it having generated the highest level of $\mathrm{O}_{2}\left({ }^{1} \Delta_{\mathrm{g}}\right)$. These data suggest that the effectiveness of the photodynamic oxidation of $\operatorname{PrP}^{\mathrm{TSE}}$ is not entirely dependent on the level of produced $\mathrm{O}_{2}\left({ }^{1} \Delta_{\mathrm{g}}\right)$ and that the prion strains differ in their susceptibility to photodynamic oxidation. The half-life of $\mathrm{O}_{2}\left({ }^{1} \Delta_{\mathrm{g}}\right)$ is just $3.5 \mu$ s [24], and it is able to oxidize targets only in close proximity to the site of its production [25]. Our previous studies with $\mathrm{AlPcOH}\left(\mathrm{SO}_{3}\right)_{2}$ demonstrated that the signal of $\mathrm{PrP}^{\mathrm{TSE}}$ is more readily removed than the signal of $\operatorname{PrP}^{C}[9,10]$. A plausible explanation of this phenomenon may be that the multimeric beta sheet rich structure of $\mathrm{PrP}^{\mathrm{TSE}}$ provides higher affinity binding sites for $\mathrm{AlPcOH}\left(\mathrm{SO}_{3}\right)_{2}$ than $\mathrm{PrPC}^{\mathrm{C}}$ and that the Pc binding leads to a more effective local production of $\mathrm{O}_{2}\left({ }^{1} \Delta_{\mathrm{g}}\right)$. The local production of $\mathrm{O}_{2}\left({ }^{1} \Delta_{\mathrm{g}}\right)$ was proposed as a cause of the photodynamic suppression of $\beta$-amyloid aggregation by porphyrins [26]. Both $\pi-\pi$ and electrostatic interactions were involved in the binding of Pcs tetrasulfonate derivatives to recombinant hamster prion protein [18]. It is tempting to speculate that two hydroxyl groups of $\mathrm{SiPc}(\mathrm{OH})_{2}\left(\mathrm{SO}_{3}\right)_{1-3}$ which are protruding above and below the planar Pc molecule and are known to prevent its self-aggregation may also prevent its $\pi-\pi$ interactions with $\mathrm{PrP}^{\mathrm{TSE}}$ [27]. The lack of local $\mathrm{O}_{2}\left({ }^{1} \Delta_{\mathrm{g}}\right)$ production, then, may make $\mathrm{SiPc}(\mathrm{OH})_{2}\left(\mathrm{SO}_{3}\right)_{1-3}$ the least effective derivative in removing $\mathrm{PrP}^{\mathrm{TSE}}$ epitopes. In contrast, the binding of less popu- 
lated $\mathrm{ZnPc}\left(\mathrm{SO}_{3}\right)_{1-3}$ monomers to $\mathrm{PrP}^{\mathrm{TSE}}$ by $\pi-\pi$ interactions is preserved, causing its higher efficacy despite significantly lower overall $\mathrm{O}_{2}\left({ }^{1} \Delta_{\mathrm{g}}\right)$ production. The highest effectiveness of $\mathrm{AlPcOH}\left(\mathrm{SO}_{3}\right)_{2}$ seems to correlate with its ability to participate in $\pi-\pi$ interactions and to produce a high level of $\mathrm{O}_{2}\left({ }^{1} \Delta_{\mathrm{g}}\right)$.

The studied prion strains could be divided into three groups differing in their sensitivity to Pc-induced photodynamic oxidation. Most resistant were the mouse-adapted sheep scrapie strains ME7 and 22L. The second group consisted of mBSE and mvCJD. The least resistant strains were RML, 139A and Fu-1. The grouping seemed to follow strain-specific characteristics as the strains known to be related, such as mBSE and mvCJD or RML and 139A, clustered together. The different susceptibility of the strains to the photodynamic oxidation probably stem from diverse conformation of the associated $\mathrm{PrP}^{\mathrm{TSE}}$. Both the size and stability of $\mathrm{PrP}^{\mathrm{TSE}}$ aggregates, surface accessibility of sensitive amino acid residues and perhaps also the ability to interact with Pcs may play important roles. For example, RML prions are smaller and less stable than ME7 prions [8], and according to our data, they are also more prone to photodynamic oxidation.

In conclusion, our data document that the sensitivity of $\mathrm{PrP}^{\mathrm{TSE}}$ to Pc induced photodynamic oxidation is prion-strain-specific. It underlines the requirement of using a range of relevant prion strains for effectiveness validation of photodynamic prion inactivation procedures. In addition, our finding offers a new way to discriminate prion strains in vitro. The photodynamic treatment is straightforward, and the removal of $\mathrm{PrP}^{\mathrm{TSE}}$ epitopes can be classified simply as yes or no. An important finding of our study is that the efficacy of Pc derivatives does not depend only on the level of $\mathrm{O}_{2}\left({ }^{1} \Delta_{\mathrm{g}}\right)$ production but also on their structural features. Most likely the binding of Pcs to PrPTSE, possibly via $\pi-\pi$ interactions, is essential for more effective local production of $\mathrm{O}_{2}\left({ }^{1} \Delta_{\mathrm{g}}\right)$. This finding warrants further studies of Pc interactions with PrP ${ }^{\mathrm{TSE}}$, which may help to improve the effectiveness of the treatment to the level allowing its utilization as a convenient method for prion decontamination.

\section{Materials and Methods}

\subsection{Phthalocyanine Derivatives Characterization}

The phthalocyanine derivatives $\mathrm{AlPcOH}\left(\mathrm{SO}_{3}\right)_{2}, \mathrm{ZnPc}\left(\mathrm{SO}_{3}\right)_{1-3}$ and $\mathrm{SiPc}(\mathrm{OH})_{2}\left(\mathrm{SO}_{3}\right)_{1-3}$ were provided by Centre for Organic Chemistry (Rybitvi, Czech Republic). The Pcs were diluted in PBS pH 7.4 to a concentration $100 \mu \mathrm{g} \mathrm{mL}{ }^{-1}$. Spectra of Pc derivatives were recorded for $10 \mu \mathrm{g} \mathrm{mL} \mathrm{mL}^{-1}$ solution in PBS and in DMSO $(n=2)$ to monitor their level of aggregation [22]. The production of singlet oxygen was measured using the iodide method [23]. Briefly, the Pcs were diluted $\left(1 \mu \mathrm{g} \mathrm{mL}{ }^{-1}\right)$ in the iodide solution (80 mM potassium iodide, $42 \mathrm{mM}$ potassium dihydrogenphosphate, $27 \mu \mathrm{M}$ ammonium molybdate, $\mathrm{pH}$ 6.2) and illuminated in a 96-well plate for $90 \mathrm{~min}$ as described in Section 4.3. The generated $\mathrm{O}_{2}\left({ }^{1} \Delta_{\mathrm{g}}\right)$ oxidize $\mathrm{I}^{-}$to $\mathrm{I}_{3}{ }^{-}$which absorbs at 287 and $351 \mathrm{~nm}$, and its absorption is proportional to $\mathrm{O}_{2}\left({ }^{1} \Delta_{\mathrm{g}}\right)$ concentration. Controls were represented by illuminated iodide solution and the solution with Pcs kept in dark. Spectrometric measurements were performed by Biochrom WPA Biowave S2100 Diode Array spectrophotometer in UV cuvettes (Brand $\mathrm{GmbH}+\mathrm{CO}$, Liebenscheid, Germany) of $10 \mathrm{~mm}$ path length.

\subsection{Tissue Samples}

The archive frozen $10 \%$ brain homogenates $(w / v$ in PBS pH 7.4, 2 mM EDTA, $1 \mathrm{mM}$ PMSF) of symptomatic CD1 mice infected with the strains ME7, 22L, 139A, RML, Fu-1, mvCJD and mBSE were utilized as the source of prions. The mice were inoculated intracerebrally with $1 \%$ infectious brain homogenate, as described previously [10]. After reaching the terminal disease phase, the animals were sacrificed, and their tissues were harvested. The experiments were carried out in accordance with the good animal practice recommended by the Federation of Laboratory Animal Science Associations and approved by the Charles University Committee on the Ethics of Animal Experiments. 


\subsection{Photodynamic Oxidation of $\operatorname{Pr} P^{T S E}$}

Photodynamic treatment of the brain homogenates was performed as described previously [10]. Briefly, $1 \%(w / v)$ brain homogenate was mixed (9:1) with Pc solution to obtain its final concentration $1 \mu \mathrm{g} \mathrm{mL} \mathrm{mL}^{-1}$. The illumination was performed in 96-well plate using a diode array light source equipped with LEDs of $100 \mathrm{~mW}$ power and the emission maximum at $655 \mathrm{~nm}$ (W53SRC/E, Kingbright, Taiwan) for $90 \mathrm{~min}$. One aliquot of the sample was treated with $50 \mu \mathrm{g} \mathrm{mL}-1$ proteinase $\mathrm{K}$ for $30 \mathrm{~min}$ at $37^{\circ} \mathrm{C}$ to prepare proteinase K-resistant fraction of $\mathrm{PrP}^{\mathrm{TSE}}$.

\subsection{Western Blotting}

Proteins resolved by sodium dodecyl sulphate polyacrylamide gel electrophoresis in $10 \%$ polyacrylamide gels were transferred onto $0.2 \mu \mathrm{m}$ nitrocellulose membrane as described previously [28]. Proteinase K-resistant $\operatorname{PrP}^{\mathrm{TSE}}$ was probed with mouse monoclonal antibodies $\left(0.5 \mu \mathrm{g} \mathrm{mL}^{-1}\right)$ AG4, BE12, AH6, GE8 (cat. no. RC059, RC060, RC058, RC061, TSE Resource Center, Roslin, UK), DC2 (Blood Transfusion Center of Slovenia, Ljubljana, Republic of Slovenia), 6D11 (cat. no. 808002, BioLegend, San Diego, CA, USA), 6H4 (cat. no. 7500996, Thermo Fisher Scientific, Waltham, MA, USA) or human monoclonal antibody D18 (provided by Dr. Burton, The Scripps Research Institute, San Diego, CA, USA). Bound antibodies were visualized using alkaline phosphatase conjugated donkey $\mathrm{F}\left(\mathrm{ab} \mathrm{b}^{\prime}\right)_{2}$ fragment anti-mouse IgG $\left(0.22 \mu \mathrm{g} \mathrm{mL}^{-1}\right.$, cat. no. 715-056-150, Jackson ImunnoResearch, La Jolla, CA, USA) or mouse anti-human IgG (1:1000, cat. no. 9042-04, Southern Biotech, Tuscaloosa, Alabama, USA) and colorimetric detection with BCIP/NBT substrate (Millipore, Burlington, MA, USA). The membranes were digitized on a Canon CanoScan LiDE 220 scanner. The signal of $\operatorname{PrP}^{\mathrm{TSE}}$ bands (di-, mono- and unglycosylated form) was quantified using the ImageJ software [29]. The statistic and other calculations were performed in GraphPad Prism 5, version 5.03. Values were expressed as mean \pm standard deviation (SD). Values with $p<0.05$ were considered statistically significant.

Author Contributions: Conceptualization, M.K. and K.H.; methodology, M.K.; validation, M.K.; formal analysis, M.K. and K.H.; investigation, M.K.; resources, M.K. and K.H.; data curation, M.K.; writing—original draft preparation, M.K.; writing—review and editing, K.H.; visualization, M.K.; supervision, K.H.; project administration, M.K.; funding acquisition, M.K. and K.H. All authors have read and agreed to the published version of the manuscript.

Funding: This research was funded by Grantova Agentura, Univerzita Karlova, project GAUK 140215 and by Agentura Pro Zdravotnicky Vyzkum Ceske Republiky, grant number NV18-04-00179. MK was supported in part by Univerzita Karlova v Praze, project PRIMUS/MED/008.

Institutional Review Board Statement: Animal procedures were carried out in agreement with the good animal practice recommended by the Federation of Laboratory Animal Science Associations. Experiments involving animals were approved by the Charles University Committee on the Ethics of Animal Experiments under the protocol numbers 390/11 and 661/18 and were performed in accordance with the Czech animal protection law (act no. 246/1992 Coll., as amended).

Informed Consent Statement: Not applicable.

Data Availability Statement: The data supporting the results presented in this study are available on request from the corresponding author.

Acknowledgments: We would like to thank Alena Lisakova for excellent technical support, Jan Rakusan and Lubomir Kubac (Centre for Organic Chemistry) for donation of phthalocyanine derivatives, Vladka Curin Serbec (Blood Transfusion Center of Slovenia) and Dennis Burton (The Scripps Research Institute) for donation of antibodies. The RML5 scrapie strain was provided by Adriano Aguzzi (Institute of Neuropathology, University of Zurich, Switzerland); the strains Fu-1, mBSE, mvCJD by Larisa Cervenakova (American National Red Cross, Rockville, Maryland); and strains ME7, 22L, 139A by TSE Resource Centre (Roslin Institute, University of Edinburgh, Scotland).

Conflicts of Interest: The authors declare no conflict of interest. 
Sample Availability: Samples of the compounds $\left(\mathrm{AlPcOH}\left(\mathrm{SO}_{3}\right)_{2}, \mathrm{ZnPc}\left(\mathrm{SO}_{3}\right)_{1-3}, \mathrm{SiPc}(\mathrm{OH})_{2}\left(\mathrm{SO}_{3}\right)_{1-3}\right)$ are available on request from the corresponding author.

\section{References}

1. Morales, R.; Abid, K.; Soto, C. The prion strain phenomenon: Molecular basis and unprecedented features. Biochim. Biophys. Acta 2007, 1772, 681-691. [CrossRef]

2. Carta, M.; Aguzzi, A. Molecular foundations of prion strain diversity. Curr. Opin. Neurobiol. 2021, 72, 22-31. [CrossRef]

3. Taylor, D.M. Resistance of transmissible spongiform encephalopathy agents to decontamination. Contrib. Microbiol. 2004, 11, 136-145. [CrossRef] [PubMed]

4. Hughson, A.G.; Race, B.; Kraus, A.; Sangare, L.R.; Robins, L.; Groveman, B.R.; Saijo, E.; Phillips, K.; Contreras, L.; Dhaliwal, V.; et al. Inactivation of Prions and Amyloid Seeds with Hypochlorous Acid. PLoS Pathog. 2016, 12, e1005914. [CrossRef] [PubMed]

5. Lehmann, S.; Pastore, M.; Rogez-Kreuz, C.; Richard, M.; Belondrade, M.; Rauwel, G.; Durand, F.; Yousfi, R.; Criquelion, J.; Clayette, P.; et al. New hospital disinfection processes for both conventional and prion infectious agents compatible with thermosensitive medical equipment. J. Hosp. Infect. 2009, 72, 342-350. [CrossRef]

6. Peretz, D.; Supattapone, S.; Giles, K.; Vergara, J.; Freyman, Y.; Lessard, P.; Safar, J.G.; Glidden, D.V.; McCulloch, C.; Nguyen, H.O.; et al. Inactivation of prions by acidic sodium dodecyl sulfate. J. Virol. 2006, 80, 322-331. [CrossRef]

7. Marin-Moreno, A.; Aguilar-Calvo, P.; Moudjou, M.; Espinosa, J.C.; Beringue, V.; Torres, J.M. Thermostability as a highly dependent prion strain feature. Sci. Rep.-UK 2019, 9, 11396. [CrossRef] [PubMed]

8. Thackray, A.M.; Hopkins, L.; Klein, M.A.; Bujdoso, R. Mouse-adapted ovine scrapie prion strains are characterized by different conformers of PrPSc. J. Virol. 2007, 81, 12119-12127. [CrossRef]

9. Janouskova, O.; Rakusan, J.; Karaskova, M.; Holada, K. Photodynamic inactivation of prions by disulfonated hydroxyaluminium phthalocyanine. J. Gen. Virol. 2012, 93, 2512-2517. [CrossRef]

10. Kostelanska, M.; Freisleben, J.; Backovska Hanusova, Z.; Mosko, T.; Vik, R.; Moravcova, D.; Hamacek, A.; Mosinger, J.; Holada, K. Optimization of the photodynamic inactivation of prions by a phthalocyanine photosensitizer: The crucial involvement of singlet oxygen. J. Biophotonics 2019, 12, e201800340. [CrossRef] [PubMed]

11. Cervenakova, L.; Akimov, S.; Vasilyeva, I.; Yakovleva, O.; McKenzie, C.; Cervenak, J.; Piccardo, P.; Asher, D.M. Fukuoka-1 strain of transmissible spongiform encephalopathy agent infects murine bone marrow-derived cells with features of mesenchymal stem cells. Transfusion 2011, 51, 1755-1768. [CrossRef]

12. Giles, K.; Berry, D.B.; Condello, C.; Hawley, R.C.; Gallardo-Godoy, A.; Bryant, C.; Oehler, A.; Elepano, M.; Bhardwaj, S.; Patel, S.; et al. Different 2-Aminothiazole Therapeutics Produce Distinct Patterns of Scrapie Prion Neuropathology in Mouse Brains. J. Pharmacol. Exp. Ther. 2015, 355, 2-12. [CrossRef]

13. Oelschlegel, A.M.; Fallahi, M.; Ortiz-Umpierre, S.; Weissmann, C. The extended cell panel assay characterizes the relationship of prion strains RML, 79A, and 139A and reveals conversion of 139A to 79A-like prions in cell culture. J. Virol. 2012, 86, 5297-5303. [CrossRef]

14. Caughey, W.S.; Raymond, L.D.; Horiuchi, M.; Caughey, B. Inhibition of protease-resistant prion protein formation by porphyrins and phthalocyanines. Proc. Natl. Acad. Sci. USA 1998, 95, 12117-12122. [CrossRef]

15. Priola, S.A.; Raines, A.; Caughey, W. Prophylactic and therapeutic effects of phthalocyanine tetrasulfonate in scrapie-infected mice. J. Infect. Dis. 2003, 188, 699-705. [CrossRef]

16. Caughey, W.S.; Priola, S.A.; Kocisko, D.A.; Raymond, L.D.; Ward, A.; Caughey, B. Cyclic tetrapyrrole sulfonation, metals, and oligomerization in antiprion activity. Antimicrob. Agents Chemother. 2007, 51, 3887-3894. [CrossRef]

17. Valiente-Gabioud, A.A.; Miotto, M.C.; Chesta, M.E.; Lombardo, V.; Binolfi, A.; Fernandez, C.O. Phthalocyanines as Molecular Scaffolds to Block Disease-Associated Protein Aggregation. Acc. Chem. Res. 2016, 49, 801-808. [CrossRef]

18. Dee, D.R.; Gupta, A.N.; Anikovskiy, M.; Sosova, I.; Grandi, E.; Rivera, L.; Vincent, A.; Brigley, A.M.; Petersen, N.O.; Woodside, M.T. Phthalocyanine tetrasulfonates bind to multiple sites on natively-folded prion protein. Biochim. Biophys. Acta 2012, 1824, 826-832. [CrossRef]

19. Grebenova, D.; Cajthamlova, H.; Holada, K.; Marinov, J.; Jirsa, M.; Hrkal, Z. Photodynamic effects of meso-tetra (4sulfonatophenyl)porphine on human leukemia cells HEL and HL60, human lymphocytes and bone marrow progenitor cells. J. Photochem. Photobiol. B 1997, 39, 269-278. [CrossRef]

20. Schmidt, A.M.; Calvete, M.J.F. Phthalocyanines: An Old Dog Can Still Have New (Photo)Tricks! Molecules 2021, $26,2823$. [CrossRef]

21. Davies, M.J. Protein oxidation and peroxidation. Biochem. J. 2016, 473, 805-825. [CrossRef] [PubMed]

22. Kuznetsova, N.A.; Gretsova, N.S.; Derkacheva, V.M.; Kaliya, O.L.; Lukyanets, E.A. Sulfonated phthalocyanines: Aggregation and singlet oxygen quantum yield in aqueous solutions. J. Porphyr. Phthalocya. 2003, 7, 147-154. [CrossRef]

23. Mosinger, J.; Mosinger, B. Photodynamic sensitizers assay: Rapid and sensitive iodometric measurement. Experientia 1995, 51, 106-109. [CrossRef]

24. Jensen, R.L.; Arnbjerg, J.; Ogilby, P.R. Temperature Effects on the Solvent-Dependent Deactivation of Singlet Oxygen. J. Am. Chem. Soc. 2010, 132, 8098-8105. [CrossRef] 
25. Klaper, M.; Fudickar, W.; Linker, T. Role of Distance in Singlet Oxygen Applications: A Model System. J. Am. Chem. Soc. 2016, 138, 7024-7029. [CrossRef]

26. Lee, B.I.; Lee, S.; Suh, Y.S.; Lee, J.S.; Kim, A.K.; Kwon, O.Y.; Yu, K.; Park, C.B. Photoexcited Porphyrins as a Strong Suppressor of beta-Amyloid Aggregation and Synaptic Toxicity. Angew. Chem. Int. Ed. 2015, 54, 11472-11476. [CrossRef]

27. Mitra, K.; Hartman, M.C.T. Silicon phthalocyanines: Synthesis and resurgent applications. Org. Biomol. Chem. 2021, 19, 1168-1190. [CrossRef]

28. Panigaj, M.; Glier, H.; Wildova, M.; Holada, K. Expression of prion protein in mouse erythroid progenitors and differentiating murine erythroleukemia cells. PLOS ONE 2011, 6, e24599. [CrossRef]

29. Schneider, C.A.; Rasband, W.S.; Eliceiri, K.W. NIH Image to ImageJ: 25 years of image analysis. Nat. Methods $2012,9,671-675$. [CrossRef] 